\title{
Influence of drop irrigation duration with mineralized waters on soil fatigation in intensive fruit plantations
}

\author{
Taras Fomenko*, and Valentina Popova \\ Federal State Budget Scientific Institution «North Caucasian Federal Scientific Center of Horticulture, \\ Viticulture, Wine-making», str. 40 Let Pobedy, 39, Krasnodar, 350901, Russia
}

\begin{abstract}
The scientific and practical problems of deterioration of the soil fertility of apple tree plantations under drip irrigation with mineralized waters are discussed. A significant decrease in soil biodiversity was revealed, depending on the duration of cultivation of fruit plantations. A prerequisite for biologization is an objective assessment of the availability of soil nutrients under droppers, which will reduce the load on the environment as a result of the rational use of fertilizers. The necessity of biologization of garden farming and reduction of soil fatigue is actualized. The ways of solving the problem of soil fatigue and reducing the fertility of chernozem soils in fruit plantations of areas of forced use of drip irrigation with mineralized waters are outlined.
\end{abstract}

\section{Introduction}

The intensification of modern horticulture, based on chemicalization and the use of highperformance agricultural machinery, contributes to the strengthening of soil degradation processes and the depletion of biological diversity in the soil-biotic complex [1]. The problem of modern gardening is the need to biologize production processes, improve soil condition, increase their resistance to anthropogenic loads. Soil suppressiveness is a set of biological, physico-chemical and agrochemical properties of soils that ensure the development of useful biota or suppressor organisms that suppress the parasitic activity of phytopathogens. The analysis of the state of soil fertility in various fruit growing zones revealed common scientific and practical problems: the manifestation of soil fatigue during long-term cultivation of garden crops, intensive irrational use of agrochemicals and pesticides, soil degradation as a result of drip irrigation with mineralized waters.

One of the most important problems in the cultivation of garden crops is soil fatigue. The main causes of soil fatigue are unilateral removal of nutrients, changes in the physical and chemical properties of the soil, the formation of toxic organic compounds, unidirectional decomposition of plant residues, unilateral development of individual groups of soil microflora to the detriment of other groups, the development of pathogenic soil microflora, increased reproduction of soil pests, pathogens, etc. [2,3]. Under the influence of root

\footnotetext{
${ }^{*}$ Corresponding author: sad-fertigation@mail.ru
} 
secretions in the rhizosphere of fruit plants, a specific composition of microflora is formed, micromycetes that produce phytotoxic substances develop [4, 5]. The development of soil fungi, Cylindrocarpon destructans, Fusarium spp, Rhizoctonia solani [6], Phytophthora cactor and Pythium spp. oomycetes [7], Actinomycetes and Pseudomonas fluorescens bacteria, increases and Pratylenchus Penetrans nematodes that parasitize plants and are the main pathogens of diseases [8]. The result of these infections is root rot of garden crops, mass drying and wilting of plants [9]. Systematic use of pesticides leads to the accumulation of their toxic residues in the soil, contributes to the change of the soil microbiocenosis due to the intensive reproduction of pathogenic microorganisms [10].

During the dry summer period, fertigation allows maintaining optimal soil moisture and supplying plants with a balanced amount of nutrients in small doses according to the phases of development of fruit plants $[11,12]$. At the same time, during fertigation, negative changes in soil properties occur, there is an increase in the spatial heterogeneity of soils, excessive accumulation of individual nutrients as a result of local systematic fertilization $[13,14]$.

Most of the territories of the Kuban-Azov lowland, located in conditions of insufficient and unstable moisture, are characterized by a lack of water resources for use in agricultural production, which leads to the forced use of irrigation water that is not suitable for irrigation. The use of mineralized water in drip irrigation systems, along with a positive effect on the productivity of fruit plants [15], often contributes to the degradation of irrigated chernozem soils [16].

The purpose of the research is to evaluate the regularities of changes in the chemical and microbiological properties of the soils of fruit plantations depending on the duration of fertigation application and to determine ways to increase the environmental sustainability of irrigated chernozem soils.

\section{Materials and methods}

The studies were carried out in apple plantations cultivated in conditions of insufficient moisture in the steppe zone of the Krasnodar Region of the Russian Federation. Objects of research: apple plantations of varieties Golden Rangers, Renet Simirenko on M9 rootstock (clone T337) of various ages (2015-2019 planting). The placement scheme of trees is 4,0 x1,0 m.

According to the WRB system (2014), soil belong to Chernozems Haplic slightly leached formed on loess loam. The content of particles $<0.01 \mathrm{~mm}$ in size is $69.2 \%$ in the upper fertile soil layer. The soil of the experimental plot in the upper 0-30 cm layer was characterized by a slightly alkaline reaction of the soil medium ( $\mathrm{pH}$-water $7.72 \pm 0.11$ ), an average level of organic matter supply (Humus $3.96 \pm 0.10 \%$ ), increased nitrification capacity $\left(\mathrm{N}_{-} \mathrm{NO}_{3} 27.9\right.$ $\pm 4.4 \mathrm{mg} / \mathrm{kg})$, high availability of mobile phosphorus $\left(\mathrm{P}_{2} \mathrm{O}_{5} 48.5 \pm 5.6 \mathrm{mg} / \mathrm{kg}\right)$ and exchangeable potassium $\left(\mathrm{K}_{2} \mathrm{O} 412.5 \pm 51.1 \mathrm{mg} / \mathrm{kg}\right)$.

The annual rate of fertilization during the fertigation of young apple plantations was N46P32K41 (1st and 2nd year of the orchard growing season), in fruiting plantations it was increased to N69P46K62 (3rd - 5th year of the orchard growing season). Fertigation was carried out in dry periods every 3-4 days from flowering to fruit ripening; on average, up to 38 waterings are carried out during the growing season.

Soil samples were taken from the 0-30 cm layer with a hand-held soil drill directly under the droppers, as well as at a distance of $20 \mathrm{~cm}$ and $40 \mathrm{~cm}$ from the drop point of the nutrient solution and in the center of the row spacing.

In soil samples, the reaction of the soil environment ( $\mathrm{pH}$-water), the specific electrical conductivity of the soil, the content of mineral forms of nitrogen $\left(\mathrm{N}-\mathrm{NO}_{3}\right.$ and $\left.\mathrm{N}-\mathrm{NH}_{4}\right)$, mobile forms of phosphorus $\left(\mathrm{P}_{2} \mathrm{O}_{5}\right)$ and potassium $\left(\mathrm{K}_{2} \mathrm{O}\right)$ were determined by the Machigin method according to generally accepted national standards (GOSTs- all-Union State Standard). 
Mycological analysis of soil samples was carried out by surface inoculation in Petri dishes of a diluted soil suspension with a concentration of $1: 10^{4}$ on Czapek's mineral medium. Petri dishes were placed in a thermostat for 6 days at a temperature of $+23^{\circ} \mathrm{C}$. The colonies were examined under a microscope, identified to genus, and the data obtained were recalculated per $1 \mathrm{~g}$ of absolutely dry soil.

Mathematical processing of the results was carried out by the generally accepted methods of variance, correlation and regression analysis using the Microsoft Excel 2003 software package.

\section{Results and discussion}

The features of migration of nutrients in ordinary chernozem with the systematic use of fertigation of fruit plantations have been established. A significant increase in the content of nitrate nitrogen in the soil at the periphery of the main zone of soil moisture was noted. The pronounced seasonal dynamics of changes in the content of nitrates in the soil was determined: an increase in concentration with regular fertilization during the growing season and leaching in the winter-spring period with heavy rainfall. A statistically significant positive correlation was determined for the increase in the content of mobile phosphorus $(\mathrm{r}=0.95)$ and exchangeable potassium $(\mathrm{r}=0.81)$ in the soil directly under the droppers as a result of the systematic use of fertigation. A high level of the content of these nutrients was observed already after the first year of the use of fertigation, and a constant high soil supply with these compounds remained in the fertilizer localization zone.

The source for irrigation of industrial gardens was water from the Kirpili River, which belongs to the steppe rivers of the Kuban-Priazovskaya lowland. The total salt content in the water used for irrigation exceeded the optimal permissible values and amounted to 1.613$1.757 \mathrm{~g} / \mathrm{l}$, of which the share of harmful alkaline and harmful neutral salts varied from 76.6 $\%$ at the beginning of the season to $90.3 \%$ at the end of the irrigation period. Water of this chemical composition is of limited use for drip irrigation of fruit plantations.

Regular drip irrigation of fruit plantations with mineralized waters has a significant effect on the condition of chernozem soils. Carrying out drip irrigation of fruit plantations with mineralized water led to an increase in soil alkalinity. This was manifested in the first years of garden irrigation, the indicators of the reaction of the soil environment in the soil directly under the droppers increased by an average of 11.3-12.0\% compared to the soil outside the wetted zone. The maximum accumulation of water-soluble salts in the zone of local soil moisture was established in the dry summer period (July-August) at a distance of $20 \mathrm{~cm}$ from the droppers. Indicators of specific electrical conductivity of the soil were 0.701 $\mathrm{mS} / \mathrm{cm}$ in apple plantations of the first year, $1.140 \mathrm{mS} / \mathrm{cm}$ in the second year, $1.211 \mathrm{mS} / \mathrm{cm}$ in the third year of vegetation. A statistically significant correlation was established between a decrease in the content of exchangeable calcium $(r=0.89)$ and an increase in exchangeable magnesium $(r=0.92)$ in the soil directly under the droppers. The increased sodium content in irrigation water also led to a significant increase in its concentration in the zone of local soil moisture. The content of exchangeable sodium in the soil directly under the droppers varied from 1.32 to $2.78 \mathrm{mg}$-eq/100g. soil.

The soil in the first year after planting the orchard was characterized by high biotic suppression. In the soil under the droppers, the proportion of suppressors was $90.8 \%$, and at a distance of $40 \mathrm{~cm}$ from the point of application of the mineral fertilizer solution, $81.3 \%$ of the total amount of fungi. The soil in the center of the row spacing in the first year of the growing season of trees was kept under black fallow, where the highest amount fungi of Trichoderma was found, the proportion of which was $30.4 \%$ of the proportion of suppressors (table). 
Table. The structure of micromycete communities in the soil of apple plantations with regular use of fertigation (selection on 28.08.2019), thous. fungi propagules in $1 \mathrm{~g}$ dry soil

\begin{tabular}{|c|c|c|c|c|c|c|c|c|c|c|c|c|c|}
\hline \multirow{2}{*}{$\begin{array}{c}\text { Place } \\
\text { of soil sampling }\end{array}$} & \multirow[b]{2}{*}{$\begin{array}{l}\text { The } \\
\text { number } \\
\text { of all } \\
\text { fungi }\end{array}$} & \multicolumn{7}{|c|}{ Phytopathogens } & \multicolumn{3}{|c|}{ Suppressors } & \multicolumn{2}{|c|}{$\begin{array}{c}\text { Other } \\
\text { saproths }\end{array}$} \\
\hline & & 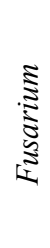 & 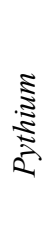 & 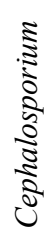 & 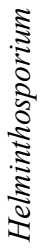 & 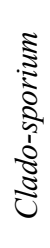 & 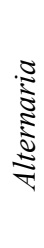 & 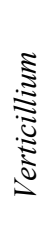 & 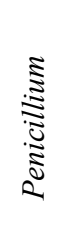 & 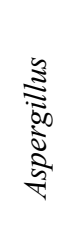 & 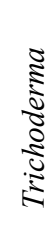 & 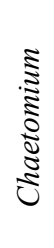 & 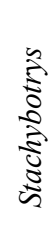 \\
\hline \multicolumn{14}{|c|}{ Planting age 1 year } \\
\hline Under irrigation & 152 & 14 & - & - & - & - & - & - & 64 & 74 & - & - & - \\
\hline $20 \mathrm{~cm}$ from irrigation & 52 & 10 & - & - & - & - & 2 & - & 18 & 16 & - & 4 & 2 \\
\hline $40 \mathrm{~cm}$ from irrigation & 96 & 10 & - & - & - & - & - & - & 44 & 32 & 2 & 8 & - \\
\hline Row-spacing & 52 & 6 & - & - & - & - & - & - & 10 & 22 & 14 & - & - \\
\hline \multicolumn{14}{|c|}{ Planting age 2 years } \\
\hline Under irrigation & 100 & 28 & - & - & 4 & 4 & 2 & 12 & 14 & 26 & - & 8 & 2 \\
\hline $20 \mathrm{~cm}$ from irrigation & 76 & 10 & - & 4 & - & 4 & 4 & - & 24 & 16 & 4 & 10 & - \\
\hline $40 \mathrm{~cm}$ from irrigation & 76 & 14 & - & 2 & - & 4 & 2 & - & 4 & 30 & 2 & 12 & 6 \\
\hline Row-spacing & 116 & 10 & - & - & - & 4 & 8 & 52 & 12 & 6 & 6 & 8 & 10 \\
\hline \multicolumn{14}{|c|}{ Planting age 3 years } \\
\hline Under irrigation & 114 & 24 & - & 16 & - & - & - & - & 36 & 34 & - & 4 & - \\
\hline $20 \mathrm{~cm}$ from irrigation & 94 & 8 & 8 & 2 & - & 2 & 4 & 2 & 32 & 34 & - & - & 2 \\
\hline $40 \mathrm{~cm}$ from irrigation & 90 & 8 & - & 4 & - & 10 & 8 & 10 & 16 & 34 & - & - & - \\
\hline Row-spacing & 100 & 16 & - & 24 & - & - & 6 & - & 38 & 8 & 4 & 4 & - \\
\hline \multicolumn{14}{|c|}{ Planting age 4 years } \\
\hline Under irrigation & 254 & 8 & - & - & - & - & - & - & 56 & 188 & 2 & - & - \\
\hline $20 \mathrm{~cm}$ from irrigation & 112 & - & - & - & - & - & - & 10 & 56 & 44 & 2 & - & - \\
\hline $40 \mathrm{~cm}$ from irrigation & 196 & 10 & - & - & - & 2 & - & - & 92 & 88 & 4 & - & - \\
\hline Row-spacing & 82 & 4 & - & 4 & - & 2 & 8 & 4 & 34 & 26 & - & - & - \\
\hline \multicolumn{14}{|c|}{ Planting age 5 years } \\
\hline Under irrigation & 214 & - & - & - & - & - & - & - & 6 & 208 & - & - & - \\
\hline $20 \mathrm{~cm}$ from irrigation & 238 & 6 & - & - & - & 6 & - & - & 120 & 98 & 8 & - & - \\
\hline $40 \mathrm{~cm}$ from irrigation & 156 & 10 & - & - & - & 4 & - & - & 46 & 94 & 2 & - & - \\
\hline Row-spacing & 92 & 26 & - & - & - & 4 & 4 & - & 40 & 18 & - & - & - \\
\hline
\end{tabular}

In the garden of the second year of vegetation, the accumulation of pathogenic soil microflora was established, and conditional suppressors (fungi of the genus Penicillium and Aspergillus) developed predominantly as antagonists. In a three-year-old garden, a significant decrease in the number of Trichoderma fungi, the most active soil suppressor, was found.

In fruiting fruit plantations (4-5 years of vegetation), there was a significant decrease in soil biodiversity, as well as in the number of Trichoderma fungi, the share of which did not exceed $3.3 \%$ of the total of all suppressors. In the soil directly under the droppers, fungi of the genus Aspergillus predominated. These fungi secrete substances that can inhibit plant growth (mycotoxins), which leads to the manifestation of soil fatigue in fruit plantations. A 
decrease in the biodiversity of soil microflora in the zone of local soil moisture is possibly due to a periodic increase in soil alkalinity during the dry summer period.

In fruit plantations of five years of age, a tendency was noted for an increase in the number of Fusarium fungi in the soil with distance from the drop of the nutrient solution to the center of the garden row spacing, exceeding the threshold value of 1000 pcs. propagules per $1 \mathrm{~g}$ of dry soil. In the soil at a distance of $20 \mathrm{~cm}$ from the droppers, suppressive microflora is sufficient to curb the development of pathogens. However, in the soil at a distance of $40 \mathrm{~cm}$ from the droppers and in the center of the row spacing, the content of suppressor fungi (fungi of the genera Penicillium, Aspergillus and Trichoderma) is insufficient, and the pathogenic background is critically high.

As the research results convince, with a perennial permanent culture, which are fruit plantations, in the areas of forced use of drip irrigation with saline waters, it is necessary to restructure the technological methods of cultivation to preserve and reproduce the fertility of chernozem soils. The ways of solving the problem are determined in several directions. There is a need to stop irrigation of chernozem soils and switch to another type of plantations. The establishment of new plantations of apple trees on medium-sized (MM106) and semi-dwarf rootstocks (SK2U) with a deeper root system and resistant to the stress effects of summer temperatures, in combination with soil mulching, will eliminate or significantly reduce drip irrigation. The use of effective agricultural practices that neutralize the effect of saline irrigation water on the properties of chernozems, including the use of resource-saving (scarce) irrigation methods, chemical reclamation (gypsum) to reduce the alkalinity of the soil, mulching near-trunk strips with plant materials (straw or wood chips) to retain moisture and improve microbiological soil activity, the introduction of organic fertilizers (based on liquid manure or poultry droppings), the use of soil improvers of organic origin. A prerequisite for the biologization of production processes in horticultural agrocenoses is an objective assessment of the supply of nutrients to the soil under droppers and the rational use of fertilizers, which makes it possible to reduce the load on the environment. The development of biologized agricultural practices will help prevent soil fatigue in gardens or eliminate its consequences.

\section{Conclusion}

The features of the migration of nutrients in the soil with the systematic use of fertigation of fruit plantations have been established. A pronounced seasonal dynamics of changes in the content of nitrate nitrogen was established: an increase in the concentration in the soil with the regular use of fertigation and partial leaching of undigested nitrogen in the winter-spring period. A significant increase in the content of mobile phosphorus and exchangeable potassium in the soil directly under the droppers was revealed as a result of the systematic use of fertigation. Drip irrigation with saline waters led to a significant change in the content of exchangeable cations in the soil absorbing complex (SAC) of irrigated soils. A statistically significant correlation was established between a decrease in the content of exchangeable calcium and an increase in exchangeable magnesium in the soil directly under the droppers. The increased sodium content in irrigation water also led to a significant increase in its concentration in the zone of local soil moisture from 1.32 to $2.78 \mathrm{meq} / 100 \mathrm{~g}$ soil. In ordinary chernozem, a significant decrease in soil biodiversity has been established, depending on the duration of cultivation of fruit plantations. From the second year of the growing season of the garden, changes were noted in the structure of soil fungi, the accumulation of pathogenic soil microflora; conditional suppressors (fungi of the genus Penicillium and Aspergillus) developed mainly as antagonists. From the age of three years in the garden, a significant decrease in the number of Trichoderma fungi, the most active soil suppressor, was established. On the basis of the results obtained, ways of solving the problem are outlined, 
which are based on the biologization of agro-technological elements of the technology of cultivation of intensive fruit plantations.

Acknowledgments. The reported study was funded by RFBR according to the research project № 1944-233010 r_mol_a and public assignment of the Ministry of Science and Higher Education of the Russian Federation

\section{References}

1. E. Egorov, Z. Shadrina, G. Kochyan, BIO Web Conf., 25, 01001 (2020) https://doi.org/10.1051/bioconf/20202501001

2. F. Mahnkopp, M. Simon, E. Lehndorff, S. Pätzold, A. Wrede, T. Winkelmann, Sci. Hortic., 241, 167-177 (2018) https://doi.org/10.1016/j.scienta.2018.06.076

3. U. Cavael, K. Diehl, P. Lentzsch, Ecol. Indic., 109, 105846 (2020) https://doi.org/10.1016/j.ecolind.2019.105846

4. R. Leisso, D. Rudell, M. Mazzola, Soil Biol. Biochem., 113, 201-214 (2017) https://doi.org/10.1016/j.soilbio.2017.06.011

5. S. Reim, C. Siewert, T. Winkelmann, T. Wöhner, M.V. Hanke, H. Flachowsky, Sci. Hortic., 256, 108517 (2019) https://doi.org/10.1016/j.scienta.2019.05.044

6. Y.T. Tewoldemedhin, M. Mazzola, I. Labuschagne, A. McLeod, Soil Biol. Biochem., 43(9), 917-1927 (2011) https://doi.org/10.1016/j.soilbio.2011.05.014

7. B. Emmett, E.B. Nelson, A. Kessler, T.L. Bauerle, Planta, 239(2), 325-340 (2014) https://doi.org/10.1007/s00425-013-1989-7

8. L.M. Manici, M. Kelderer, I.H. Franke-Whittle, T. Rühmer, G. Baab, F. Nicoletti, F. Caputo, A. Topp, H. Insam, A. Naef, Appl. Soil Ecol., 72, 207-214 (2013) https://doi.org/10.1016/j.apsoil.2013.07.011

9. R.C. Gergerich, R.A. Welliver, S. Getty, N.K. Osterbauer, S. Kamenidou, R.R. Martin, D.A. Golino, K. Eastwell, M. Fuchs, G. Vidalakis, I.E. Tzanetakis, Plant Dis., 99 (2), 176-187 (2015) https://doi.org/10.1094/PDIS-07-14-0762-FE

10. M.E. Podgornaya, Horticulture and viticulture. 6, $36-40 \quad$ (2016) https://doi.org/10.18454/VSTISP.2016.6.3915

11. B.F. Kühn, M. Bertelsen, L. Sørensen, Sci. Hortic., 129(3), 369-375 (2011) https://doi.org/10.1016/j.scienta.2011.03.033

12. A.I. Kuzin, Yu.V. Trunov, A.V. Solovyev, Agric. Biol., 53(5), 1013-1024 (2018) https://doi.org/10.15389/agrobiology.2018.5.1013eng

13. T.G. Fomenko, V.P. Popova, N.G. Pestova, Russ. Agric. Sci., 41(4), 247-251 (2015) https://doi.org/10.3103/S1068367415040060

14. R. Čabilovski, A. Brayek, N. Magazin, K. Petković, M. Manojlović, J. Agric. Sci., 25(4), 481-490 (2019) https://doi.org/10.15832/ankutbd.410265

15. T.G. Fomenko, V.P. Popova, K.V. Belousova, Horticulture and Viticulture, 2, 10-17 (2019) https://doi.org/10.31676/0235-2591-2019-2-10-17

16. T.G. Fomenko, V.P.Popova, E.A. Chernikov, Russ. Agric. Sci.,. 44 (3), 260-264 (2018) https://doi.org/10.3103/S1068367418030047 